\title{
PERANAN LAPORAN KEUANGAN DALAM KEBIJAKSANAAN PEMBERIAN KREDIT KEPADA CALON NASABAH PADA PT. BPR BATANG KAPAS
}

\author{
Ananda Rahmi Sanjaya, Doni marlius \\ Akademi Keuangan dan Perbankan Padang \\ donimarlius@akbpstie.ac.id
}

\begin{abstract}
The objective to be achieved in this study is to find out how the financial statement analysis of PT. BPR Batang Kapas in giving credit to prospective customers. In analyzing data, the author uses qualitative data analysis as a research method that explains descriptively about the role of financial statements in the policy of giving credit to prospective customers of PT. BPR Batang Kapas. Research Results The total operating income of PT. BPR Batang Kapas in 2015 was Rp. 4,127,157,198 while in 2016 it was Rp. 4,614,930,633. While the operating profit and loss of PT. BPR Batang Kapas in 2015 was IDR 552,086,280 and in 2016 was IDR 627,180,472. it can be seen that the national financial profit of PT. BPR Batang Kapas has increased by $R p$ 75,094,192. It is clear that PT. BPR Batang Kapas benefited from 2015 to 2016. Both in terms of the amount of operating income, operating income or net income at PT. BPR Batang Kapas. But based on the data on the ratio of Liquidity, Solvability, and Profitability see the percentage that exists at PT. BPR Batang Kapas, there is a possibility that credit can be given to prospective customers.
\end{abstract}

Keywords: Financial Reports, Credit Giving Policy

\section{Latar Belakang Masalah}

Bank Perkreditan Rakyat

( BPR ) adalah salah satu jenis bank yang dikenal melayani golongan pengusaha mikro, kecil dan menengah. BPR merupakan lembaga perbankan resmi yang diatur berdasarkan Undang-Undang No. 7 tahun 1992 tentang Perbankan dan sebagaimana telah diubah dengan Undang-undang No. 10 tahun 1998. Fungsi BPR tidak hanya sekedar menyalurkan kredit kepada para pengusaha mikro, kecil dan menengah, tetapi juga menerima simpanan dari masyarakat. Dalam penyaluran kredit kepada masyarakat menggunakan prinsip 3T, yaitu tepat waktu, tepat jumlah, tepat sasaran, karena proses kreditnya yang relatif cepat, dan persyaratannya lebih sederhana. .Persaingan yang semakin ketat di dunia bisnis, menuntut perusahaan termasuk perbankan untuk 
mengembangkan strategi strategi dalam menjalankan usahanya. Strategi ini bertujuan untuk menciptakan keunggulan kompetitif, pertumbuhan serta pengembangan perusahaan. Masyarakat sangat membutuhkan kehadiran bank sebagai sarana penyimpanan maupun membantu dalam usaha masyarakat baik usaha kecil maupun menengah ke atas. Dalam penilaian kinerja bank diperlukan suatu tolak ukur untuk mengukur kemampuan hasil usaha tersebut, antara lain dengan menggunakan rasio keuangan perbankan yang meliputi ratio likuiditas, solvabilitas dan profitabilitas. Rasio Likuiditas menurut Fred Weston dikutip dari Kasmir (2008:129), menyebutkan bahwa rasio likuiditas "(liquidity ratio) merupakan rasio yang menggambarkan kemampuan perusahaan dalam memenuhi kewajiban (utang) jangka pendek". Rasio Solvabilitas menurut Fred Weston dikutip dari Kasmir (150:2008), "Rasio Solvabilitas adalah rasio yang digunakan untuk mengukur Perumusan Masalah

Berdasarkan latar belakang yang diuraikan di atas, maka permasalahan yang diangkat penulis dalam penilitian ini adalah bagaimana analisa masalah laporan keuangan pada PT. BPR Batang Kapas dalam pemberian kredit kepada calon nasabah.

\section{Tujuan Penelitian}

Berdasarkan perumusan masalah, maka tujuan yang ingin dicapai dalam penelitian ini sejauhmana aktiva perusahaan dibiayai dengan utang dan mengukur kemampuan perusahaan untuk membayar seluruh kewajibannya, baik jangka pendek maupun jangka panajang, apabila perusahaan dilikuidasi (dibubarkan)". Rasio Profitabilitas menurut Sofyan Safri Harahap (2008:304), "Rasio profitabilitas adalah kemampuan perusahaan mendapatkan laba melalui semua kemampuan, dan sumber yang ada seperti kegiatan penjualan, kas, modal, jumlah karyawan, jumlah cabang dan sebagainya".

Dengan menggunakan rasio ini dapat diketahui apakah kinerja bank tersebut apakah meningkat atau mengalami penurunan. maka penulis tertarik untuk membahasnya di dalam suatu Tugas akhir yang berjudul "PERANAN LAPORAN KEUANGAN DALAM KEBIJAKSANAAN PEMBERIAN KREDIT KEPADA CALON NASABAH PADA PT. BPR BATANG KAPAS".

adalah mengetahui bagaimana analisa laporan keuangan PT. BPR Batang Kapas dalam pemberian kredit kepada calon nasabah.

\section{Manfaat Penelitian}

a. Bagi penulis

Adalah untuk menambah wawasan dan memperluas pola pikir secara ilmiah dalam bidang akuntansi terutama dalam memahami peranan serta pengaruh laporan keuangan 
dalam kebijaksanaan pemberian kredit.

b. Bagi pembaca

Adalah penelitian ini diharapkan dapat menjadi salah satu acuan dan referensi dalam melakukan penelitian sejenis.

c. Serta memberikan kontribusi ilmiah dalam bidang manajemen keuangan terutama yang berhubungan dengan kredit perbankan.

\section{Metode Penelitian}

Dalam pengumpulan data dan bahan untuk melakukan penelitian ini, digunakan metode-metode pengumpulan data sebagai berikut:

\section{A. Metode Pengumpulan Data}

1. Studi Lapangan (Field Research)

Peninjauan langsung ke objek penelitian dipilih untuk meneliti hasil data primer. Penelitian langsung ke lapangan ini dapat penulis untuk melengkapi data yang diperlukan. Adapun cara riset lapangan ini adalah dengan mewawancarai pihak-pihak yang berkepentingan, dalam hal ini adalah perusahaan atau instansi yang terkait.

2. Studi Kepustakaan( Library Research)

Penelitian yang dilakukan ke pustaka. Beberapa buku-buku ilmiah dan tulisan-tulisan yang berhubungan dengan pembahasan yang dilakukan.

\section{B. Metode Analisa Data}

Dalam menganalisa data, penulis menggunakan analisis data kualitatif sebagai metode penelitian yang menjelaskan secara deskriptif mengenai bagaimana peranan laporan keuangan dalam kebijaksanaan pemberian kredit kepada calon nasabah PT. BPR Batang Kapas. Metode analisis ditinjau dari dua segi yang berbedaya itu antara teori dan praktek yang perlu diterapkan, sehingga dapat diketahui sejauh mana pelaksanaannya, apakah perbedaan yang timbul menyangkut prinsip dasar konsep itu sendiri, pertanyaan itu akan terjawab, selanjutnya dari hasil analisa itu digunakan sebagai dasar pengambilan kesimpulan dan saran.

\section{Landasan Teori \\ Pengertian Bank Perkreditan Rakyat (BPR)}

Bank

Perkreditan

Rakyat (BPR) adalah lembaga keuangan bank yang menerima simpanan hanya dalam bentuk deposit

berjangka, tabungan, dan / atau bentuk lainnya yang dipersamakan dan menyalurkan dana sebagai usaha BPR. Dengan lokasi yang pada umumnya dekat dengan tempat masyarakat yang membutuhkan. Status BPR diberikan kepada Bank Desa, Lumbung Desa, 
Bank Pasar, Bank Pegawai, Lumbung Pitih Nagari (LPN), Lembaga Perkreditan Desa (LPD), Badan Kredit Desa (BKD), Badan Kredit Kecamatan (BKK), Kredit Usaha Rakyat Kecil (KURK), Lembaga Perkreditan Kecamatan (LPK), Bank Karya Produksi Desa (BKPD), dan/atau lembaga-lembaga lainnya yang dipersamakan berdasarkan UU Perbankan Nomor 7 Tahun 1992 dengan memenuhi persyaratan tatacara yang ditetapkan dengan Peraturan Pemerintah. Ketentuan tersebut diberlakukan karena mengingat bahwa lembaga-lembaga tersebut telah berkembang dari lingkungan masyarakat Indonesia, serta masih diperlukan oleh masyarakat, maka keberadaan lembaga dimaksud diakui. Oleh karena itu, UU Perbankan Nomor 7 Tahun 1992 memberikan kejelasan status lembaga-lembaga dimaksud. Untuk menjamin kesatuan dan keseragaman dalam pembinaan dan pengawasan, maka persyaratan dan tatacara pemberian status lembagalembaga dimaksud ditetapkan dengan Peraturan Pemerintah.

\section{Tugas Bank}

Perkreditan Rakyat (BPR)

Menurut pasal $13 \mathrm{UU}$ Perbankan No. 10 tahun 1998, Bank Perkreditan Rakyat mempunyai suatu kegiatan usaha yaitu sebagai berikut.

a. Bertugas untuk menghimpun dana dari masyarakat dalam bentuk simpanan yang berupa deposito berjangka, tabungan, dan/atau bentuk lainnya yang dipersamakan dengan itu.

b. Bertugas memberikan kredit.

c. Bertugas untuk menyediakan

pembiayaan dan penempatan dana berdasarkan prinsip syariah, sesuai dengan ketentuan yang ditetapkan oleh Bank Indonesia.

d. Bertugas untuk menempatkan dananya dalam bentuk Sertifikat Bank Indonesia (SBI), deposito berjangka, sertifikat deposito, dan/atau tabungan pada bank lain.

\section{Fungsi Bank Perkreditan} Rakyat (BPR)

a. Berfungsi untuk memberikan suatu pelayanan kepada masyarakat untuk menerima tabungan mereka dalam bentuk deposito berjangka, tabungan, dan/atau bentuk lainnya yang dipersamakan dengan itu.

b. Berfungsi untuk memberikan kredit.

c. Berfungsi untuk menyediakan pembiayaan bagi nasabah yang berdasarkan prinsip bagi hasil sesuai dengan ketentuan yang 

ditetapkan dalam peraturan pemerintah.
d. Berfungsi untuk menempatkan dananya dalam bentuk Sertifikat Bank Indonesia (SBI), deposito berjangka, sertifikat deposito, dan atau pada bank lain.

\section{Manfaat Menabung di BPR}

a. Suku bunga tabungan BPR kompetitif dan menarik.

b. Biaya administasi ringan bahkan ada yang bebas biaya.

c. Jaringan kantor BPR tersebar dari kota hingga ke desa.

d. Saldo minimum tabungan rendah dan setoran selanjutnya juga kecil.

e. Setoran tabungan dapat dilakukan dengan uang pecahan kecil atau receh.

f. Tabungan di BPR dapat digunakan sebagai agunan kredit.

g. Layanan jemput bola oleh petugas BPR sehingga tidak perlu repot mendatangi kantor BPR.

h. BPR dapat melayani tabungan secara berkelompok sebagai bagian dari pembiayaan.

i. Tabungan di BPR dijamin oleh Lembaga Penjamin Simpanan (LPS) sesuai dengan ketentuan dan persyaratan yang

berlalu.

\section{Pengertian Laporan Keuangan}

Pengertian laporan

keuangan dapat dipahami sebagai hasil dari proses akuntansi yang dapat digunakan sebagai alat untuk berkomunikasi antara data keuangan atau aktivitas suatu perusahaan dengan pihak-pihak yang berkepentingan dengan data atau aktivitas perusahaan. Untuk mendalami lebih jauh, berikut ini kami sajikan beberapa pengertian baik menurut Pernyataan Standar Akuntansi Keuangan (PSAK) maupun berdasarkan pendapat organisasi dan para ahli sehingga laporan keuangan dapat dipahami dengan baik.

Ikatan

Akuntan

Indonesia (2012:5)

mengemukakan pengertian laporan keuangan yaitu : Laporan keuangan merupakan struktur yang menyajikan posisi keuangan dan kinerja keuangan dalam sebuah entitas.Tujuan umum dari laporan keuangan ini untuk kepentingan umum adalah penyajian informasi mengenai posisi keuangan (financial position), kinerja keuangan (financial performance), dan arus kas (cash flow) dari entitas yang sangat berguna untuk membuat keputusan ekonomis bagi para penggunanya.Untuk dapat mencapai tujuan ini, laporan keuangan menyediakan informasi mengenai elemen dari entitas yang terdiri dari aset, kewajiban, networth, beban, dan pendapatan 
(termasuk gain dan loss), perubahan ekuitas dan arus kas. Informasi tersebut diikuti dengan catatan, akan membantu pengguna memprediksi arus kas masa depan.

Menurut Kieso, dkk (2007:2), Laporan Keuangan merupakan sarana yang bisa digunakan oleh entitas untuk mengkomunikasikan keadaan terkait dengan kondisi keuangannya kepada pihakpihak yang berkepentingan baik yang berasal dari internal entitas maupun eksternal entitas.

Menurut Kasmir (2014:6), laporan keuangan didefinisikan sebagai laporan yang menunjukkan kondisi keuangan perusahaan pada saat ini atau dalam suatu periode tertentu.

Harahap (2009:105)

mengemukakan bahwa laporan keuangan menggambarkan kondisi keuangan dan hasil usaha suatu perusahaan pada saat tertentu atau jangka waktu tertentu. Adapun jenis laporan keuangan yang lazim dikenal adalah neraca, laporan labarugi atau hasil usaha, laporan perubahan ekuitas, laporan arus kas, laporan posisi keuangan.

\section{Tujuan Laporan Keuangan}

Menurut Standar Akuntasi Keuangan (Ikatan Akuntan Indonesia 2002:4) tujuan laporan keuangan adalah sebagai berikut:

a. Menyediakan informasi yang menyangkut posisi keuangan, kinerja, seta perubahan posisi keuangan suatu perusahaan yang bermanfaat bagi sejumlah besar pemakai dalam pengambilan keputusan ekonomi.

b. Laporan keuangan yang disusun untuk tujuan ini memenuhi kebutuhan bersama sebagian besar pemakai. Namun demikian, laporan keuangan tidak menyediakan semua informasi yang mungkin dibutuhkan pemakai dalam pengambilan keputusan ekonomi karena secara umum menggambarkan pengaruh keuangan dan kejadian di masa lalu.

c. Laporan keuangan juga menunjukkan apa yang telah dilakukan manajemen (stewardship) atau pertanggunggjawaban manajemen atas sumber daya yang dipercayakan kepadanya.

\section{Pengertian Analisa Laporan Keuangan}

Analisa laporan

keuangan adalah suatu proses penelitian laporan

keuangan beserta unsurunsurnya yang bertujuan untuk mengevaluasi dan memprediksi kondisi keuangan perusahaan atau badan usaha dan juga mengevaluasi hasil-hasil yang telah dicapai perusahaan atau badan usaha pada masa lalu dan sekarang. 


\section{Rasio Likuiditas}

Rasio Likuiditas menurut Fred Weston dalam Kasmir (2012:129) merupakan rasio yang menunjukkan kemampuan suatu perusahaan untuk memenuhi kewajiban jangka pendek yang harus segera dipenuhi pada saat yang tepat. Rumus yang digunakan adalah

$$
\begin{aligned}
& \begin{array}{l}
\text { Current ratio } \\
\text { Aktiva Lancar } \\
\text { Hutang Lancar }
\end{array} \times 100 \%
\end{aligned}
$$

\section{Rasio Solvabilitas}

$$
\text { Menurut }
$$

Kasmir (2008:151) Rasio Solvabilitas adalah rasio yang menunjukkan besarnya aktiva sebuah perusahaan yang di danai dengan utang. Rumus yang digunakan adalah

$$
\begin{aligned}
& \text { Debt to Asset Ratio= } \\
& \frac{\text { Total Hutang }}{\text { Total Aktiva }} \times 100 \% \\
& \text { Quick } \\
& \text { Ratio= } \\
& \text { Aktiva Lancar-Persediaan } \\
& \text { Hutang Lancar } \quad \mathrm{x} \\
& 100 \%
\end{aligned}
$$

\section{Rasio Profabilitas}

$$
\text { Menurut R. Agus }
$$

Sartono (2010:122) Rasio

Profabilitas adalah kemampuan perusahaan mendapatkan laba

\begin{tabular}{|c|c|c|c|}
\hline No. & Rasio & $\begin{array}{l}\text { Standar } \\
\text { rata - } \\
\text { rata }\end{array}$ & Keterangan \\
\hline \multirow[t]{2}{*}{1.} & Likuditas & & \\
\hline & $\begin{array}{l}\text { Current } \\
\text { Rasio (CR) }\end{array}$ & 2 kali & bagus \\
\hline \multirow[t]{3}{*}{2.} & Solvabilitas & & \\
\hline & $\begin{array}{l}\text { Debt to } \\
\text { asset ratio }\end{array}$ & $35 \%$ & bagus \\
\hline & Quick ratio & $1,5 \mathrm{kali}$ & bagus \\
\hline \multirow[t]{3}{*}{3.} & Profabilitas & & \\
\hline & $\begin{array}{l}\text { Gross } \\
\text { Profit } \\
\text { Margin }\end{array}$ & $24,90 \%$ & bagus \\
\hline & $\begin{array}{l}\text { Net Profit } \\
\text { Margin }\end{array}$ & $20 \%$ & bagus \\
\hline
\end{tabular}
melalui semua kemampuan, dan sumber yang ada seperti kegiatan penjualan, kas, modal, jumlah karyawan, jumlah cabang dan sebagainya". Rumus yang digunakan adalah

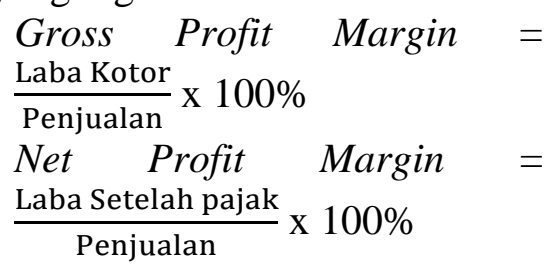

Standar rata - rata rasio

keuangan perusahaan yang sehat

Sumber: Kasmir (2008)

\section{PengertianKredit}

Kata kredit berasal dari bahasa Yunani yaitu "credere" yang berarti kepercayaan. Jadi istilah kredit memiliki arti khususya itu meminjamkan uang (penundaan pembayaran) berdasarkan kepercayaan. Maksudnya pemberi kredit percaya kepada penerima kredit bahwa kredit yang disalurkannya pasti akan dikembalikan sesuai 
perjanjian. Pada sisi penyaluran dana (lending of fund), kredit merupakan pembiayaan yang potensial menghasilkan pendapatan dibandingkan alternatif pendapatan lainnya. Sedangkan bagi penerima kredit berarti menerima kepercayaan sehingga mempunyai kewajiban untuk membayar kembali pinjaman tersebut sesuai dengan jangka waktunya. Oleh karena itu, untuk meyakinkan bank bahwa sinasabah benar - benar dapat dipercaya maka sebelum kredit diberikan terlebih dahulu bank mengadakan analisis kredit. Analisis kredit meliputi latar belakang nasabah atau perusahaan, prospek usahanya, jaminan yang diberikan serta factor - factor lainnya. Tujuan analisis ini adalah agar bank yakin bahwa kredit yang diberikan benar -benar aman. Menurut Undang - Undang Perbankan No. 10 tahun 1998, kredit adalah penyediaan uang atau tagihan yang dapat dipersamakan dengan itu, berdasarkan persetujuan atau kesepakatan pinjam meminjam antara bank dengan pihak lain yang mewajibkan pihak peminjam melunasi utangnya setelah jangka waktu tertentu dengan pemberian bunga. (Kasmir,2002) Dalam mekanisme kerja bank berkaitan dengan peranannya sebagai lembaga perantara keuangan, penyaluran dana kepada masyarakat merupakan aktivitas yang dilakukan setelah penghimpunan dana dari masyarakat. Penyaluran dana yang dilakukan adalah dalam bentuk kredit (pinjaman kepada debitur). Melalui penyaluran kredit bank memperoleh bunga sebagai pendapatan bagi bank. Terdapat beberapa alasan bank melakukan penyaluran kredit. Menurut Dahlan Siamat (2005;39), alasan atau kondisi yang mendorong hal tersebut adalah :

1. Sifat usaha bank yang berfungsi sebagai lembaga intermediasi antara unit surplus dan unit defisit.

2. Penyaluran kredit memberikan spread yang pasti sehingga besarnya pendapatan dapat diperkirakan

3. Melihat posisinya dalam bidang pelaksanaan kebijakan moneter, perbankan merupakan sector usaha yang paling diatur oleh pemerintah sehingga bank-bank dibeberapa Negara kegiatannya dibatasi

4. Sumber dana utama bank berasal dari dana masyarakat sehingga secara modal mereka harus menyalurkan kembali kepada masyarakat dalam bentuk kredit.

\section{Analisa Dan Pembahasan Rasio Likuiditas}

Rasio Likuiditas merupakan rasio yang menunjukkan kemampuan suatu perusahaan untuk memenuhi kewajiban jangka pendek yang harus segera dipenuhi pada saat yang tepat. Rasio Lancar (Current Ratio). 
Rasio ini adalah perbandingan antara aktiva lancar dengan kewajiban jangka panjang. Cara pengukurannya adalah sebagai berikut:

$$
\begin{aligned}
& \text { Current ratio }=\frac{\text { Aktiva Lancar }}{\text { Hutang Lancar }} \times \\
& 100 \%
\end{aligned}
$$

Tahun 2015 Current ratio $=$ $\frac{24.383 .506 .204}{20.809 .180 .405} \times 100 \%$

Current ratio $=1,171$

Dari data di atas, dapat disimpulkan bahwa rasio likuiditas pada PT. BPR Batang Kapas tahun 2015 adalah sebesar 1,171. Hasil tersebut bagus karna aktiva lancar bisa menutupi hutang lancar.

Tahun 2016 Curent ratio $=$ $\frac{29.956 .620 .767}{24.805 .389 .601} \times 100 \%$

Current ratio $=1,207$

Dari data di atas, dapat disimpulkan bahwa rasio likuiditas pada PT. BPR Batang Kapas tahun 2016 sebesar 1,207. Hasil tersebut bagus, karna jumlah aktiva lancar bisa menutupi jumlah hutang lancar

\section{Rasio Solvabilitas}

Rasio Solvabilitas adalah rasio yang menunjukkan besarnya aktiva sebuah perusahaan yang di danai dengan utang.

a. Debt to asset ratio

Menurut Syamsuddin (2006:30) Debt to Total Assets Ratio (DAR) digunakan untuk mengukur seberapa besar jumlah aktiva perusahaan dibiayai dengan total hutang

Debt to Asset Ratio=
$\frac{\text { Total Hutang }}{\text { Total Aktiva }} \times 100 \%$

Tahun 2015 Debt to Asset

$$
\begin{aligned}
& \text { Ratio }= \\
& 100 \%
\end{aligned} \quad \frac{24.384 .251 .323}{24.383 .506 .204} \mathrm{x}
$$

Debt to Asset Ratio=1,00

Ratio lancar pada PT.

BPR Batang Kapas tahun 2015 berdasarkan data - data yang ada adalah sebesar 1,00. Apabila di persentase kan, hasil nya menjadi $100 \%$. Hasil nya bagus, karna telah melewati standar rata - rata untuk keuangan suatu perusahaan yang sehat.

Tahun 2016 Debt to Asset

$$
\begin{gathered}
\text { Ratio }=\frac{28.793 .139 .762}{29.956 .620 .767} \times 100 \% \\
\text { Debt to Asset Ratio = } \\
\text { 0,961 } \\
\text { Ratio lancar pada PT. }
\end{gathered}
$$
BPR Batang Kapas tahun 2016 berdasarkan data - data yang ada adalah sebesar 0,961 hasil tersebut bagus. karna persentase nya mencapai $96,1 \%$

b. Rasio Cepat (Quick Ratio atau Acid Test Ratio)

Rasio cepat merupakan rasio yang menunjukkan kemampuan perusahaan dalam membayar kewajiban atau utang lancar dengan aktiva lancar tanpa memperhitungkan nilai persediaan.

$$
\begin{aligned}
& \text { Quick } \\
& \text { Ratio }= \\
& \frac{\text { Aktiva Lancar-Persediaan }}{\text { Hutang Lancar }} \mathrm{x} 100 \% \\
& \text { Tahun } 2015 \text { Quick Ratio = } \\
& \frac{24.383 .506 .204-20.809 .180 .405}{3.575 .070 .918} \quad \mathrm{X} \\
& 100 \% \\
& \text { Quick Ratio = 0,999 }
\end{aligned}
$$

Rasio cepat pada PT. BPR Batang Kapas tahun 2015 berdasarkan data- data yang ada adalah sebesar 0,999 hasil teesebut kurang bagus untuk keuangan PT. BPR Batang Kapas. Karena total aktiva 
lancer dikurang persediaan tidak bisa menutupi hutang lancar atau tidak mencapai target rata - rata keungan yang sehat.

Tahun 2016 Quick Ratio = $\frac{29.956 .620 .767-24.805 .389 .601}{3.987 .750 .161} \mathrm{x}$ $100 \%$

Quick Ratio $=1,291$

Rasio cepat pada PT. BPR Batang Kapas tahun 2016 berdasarkan data- data yang ada adalah sebesar 1,291 hasil tersebut kurang bagus untuk standar rata - rata keuangan yang sehat.

\section{Rasio Profitabilitas}

"Rasio profitabilitas adalah kemampuan perusahaan mendapatkan laba melalui semua kemampuan, dan sumber yang ada seperti kegiatan penjualan, kas, modal, jumlah karyawan, jumlah cabang dan sebagainya".

a. Margin LabaKotor (Gross Profit Margin)

Margin laba kotor adalah ukuran persentase dari setiap hasil sisa penjulan sesudah perusahaan membayar

Harga pokok penjualan.

Gross Profit Margin = $\frac{\text { Laba Kotor }}{\text { Penjualan }}$ 100\%

Tahun 2015 Groos Profit Margin $=\frac{545.285 .280}{364.722 .435} \times 100 \%$

Groos Profit Margin = 1, 495

Hasil Margin laba kotor (Gross Profit Margin) pada PT. BPR Batang Kapas tahun 2015 menurut data - data yang ada adalah sebesar 1, 495 atau sebesar $149,5 \%$. Hasil tersebut bagus, karena bisa melewati standar rata - rata untuk keuangan yang sehat.
Tahun 2016 Gross Profit

Margin $=\frac{622.380 .472}{221.733 .014} \times 100 \%$

Gross Profit Margin = 2, 806

Hasil Margin laba kotor (Gross Profit Margin) pada PT. BPR Batang Kapas tahun 2016 menurut data - data yang ada adalah sebesar 2, 806. Hasil nya bagus, karena mencapai standar rata - rata keuangan suatu perusahaan yang sehat.

b. Margin Laba Operasi (Operating Profit Margin)

Margin laba operasi adalah ukuran persentase dari setiap hasil sisa penjualan sesudah semua biaya dan pengeluaran lain dikurangi kecuali bunga dan pajak, atau laba bersih yang dihasilkan dari setiap rupiah penjualan.

Net Profit Margin = $\frac{\text { Laba Setelah pajak }}{\text { Penjualan }} \times 100 \%$

Tahun 2015 Net Profit Margin $=\frac{504.013 .708}{193.952 .818} \times 100 \%$

Net Profit Margin = 2, 598

Hasil Margin laba operasional tahun 2015 berdasarkan data - data yang di atas adalah sebesar 2,598. Hasil nya bagus karena hasil laba setelah pajak dua kali lebih banyak dari hasil penjualan.

Tahun 2016 Net Profit Margin $=\frac{576.231 .166}{221.733 .014} \times 100 \%$

Net Profit Margin = 2,598

Hasil Margin laba operasional tahun 2016 berdasarkan data - data yang di atas adalah sebesar 2,598 hasil tersebut sama seperti tahun 2015. 


\section{Pembahasan}

Berdasarkan hasil analisis terhadap data keuangan baik analisis ratio likuiditas, solvabilitas dan profitabilitas untuk menilai kinerja PT. BPR Batang Kapas. Analisis rasio likuiditas dan solvabilitas digunakan untuk menilai posisi keuangan PT. BPR Batang Kapas. Sedangkan rasio profitabilitas digunakan untuk melihat berapa keuntungan yang di dapatkan oleh PT. BPR Batang Kapas. Berdasarkan data analisis posisi keuangan PT. BPR Batang Kapas sangat baik karna mengalami kenaikan daritahun 2015 sampai tahun 2016. Baik itu Kas, Kredit, ataupun asset - asset lainnya. Begitu juga dengan keuntungan yang di dapatkan oleh PT. BPR Batang Kapas mengalami kenaikan dari tahun 2015 sampai tahun 2016. Hal ini dapat dilihat dari laporan laba rugi PT. BPR Batang Kapas dari 2015 sampai tahun 2016. Jumlah pendapatan operasional PT. BPR Batang Kapas tahun 2015 yaitu sebesar $\mathrm{Rp}$ 4.127.157.198 sedangkan tahun 2016 yaitu sebesar Rp 4.614.930.633. Sedangkan laba rugi operasional PT. BPR Batang Kapas tahun 2015 yaitu sebesar Rp 552.086.280 dan pada tahun 2016 yaitu sebesar Rp 627.180.472. dapat dilihat bahwa laba rugio perasional PT. BPR Batang Kapas mengalami kenaikan sebesar Rp 75.094.192. Jelas terlihat bahwa PT. BPR Batang Kapas mendapatkan keuntungan dari tahun 2015 sampai tahun 2016. Baik itu dari segi jumlah pendapatan operasional, laba rugi operasional ataupun laba bersih yang ada pada PT. BPR Batang Kapas. Tetapi berdasarkan data - data rasio Likuiditas, Solvabilitas, dan Profitabilitas melihat persentase yang ada pada PT. BPR Batang Kapas, maka ada kemungkinan kredit dapat diberikan kepada calon nasabah.

\section{DAFTAR PUSTAKA}

Baridwan, Zaki, 2004, Intermediate Accounting, Edisi Kedelapan, Yogyakarta; BPFE.

E. Kieso, Donald, Jerry J. Weygand and Terry D. Warfield, 2007 "Intermediate Accounting" ,Edisi 12 : by Erlangga

Horne, James C. Van \& John M, Wachowicz, JR. 2012. Prinsip-Prinsip Manajemen Keuangan (Edisi 13).Jakarta : Salemba Empat

Kasmir. 2008. Analisis Laporan Keuangan.Jakarta: Rajawali Pers.

Kasmir. (2012), Analisis Laporan Keuangan. Jakarta : PT. Raja Grafindo Persada
Munawir,2007,Analisa Laporan Keuangan. Liberty, Yogyakarta

Harahap, Sofyan Syafri. 2008. Analisis Kritis Atas Laporan Keuangan. Raja Grafindo Persada, Jakarta. 
Ikatan Akuntan Indonesia. 2012. Standar Akuntansi Keuangan. Jakarta: IAI

Farid dan siswanto, 2011, Analisis Laporan Keuangan, Jakarta, Bumi Aksara.

Fahmi, irham. 2012. Analisis Laporan Keuangan. Cetakan ke-2 Bandung Alfabeta

Kasmir. (2014). Bank dan Lembaga Keuangan Lainnya. Edisi Revisi, Cetakan keempat belas, PT. RajaGrafindo Persada, Jakarta.

Harahap, Sofyan Syafri. 2009. "Analisis Kritis Atas Laporan Keuangan". Jakarta: Raja Grafindo Persada

Ikatan Akuntan Indonesia, 2002, Standar Akuntansi Keuangan, Salemba Empat, Jakarta.

John, J. Wild. 2005. Analisis Laporan Keuangan, Buku satu, Edisi Delapan. Jakarta Salemba Empat.

Agus Sartono. (2010). Manajemen Keuangan Teori dan Aplikasi (4 th ed.). Yogyakarta: BPFE.

Sastadipoera Komaruddin. (2004). Stratei Manajemen Bisnis Perbankan. Bandung: KappaSigma. 